\title{
Soil Quality Engineering Using Vermicompost and its Effect on the Corn (Zea mays L.) Production in Coastal Area
}

\author{
Riwandi, Hasanudin, Herry Gusmara and Anandyawati \\ Soil Science Study Program, Department of Agriculture Cultivation \\ Faculty of Agriculture University of Bengkulu. Indonesia. Postcode 38371 \\ e-mail: riwandi@unib.ac.id
}

Received July 6, 2020; Revised September 18, 2020; Accepted 30 September 2020

\begin{abstract}
The low quality of Entisol is caused by low availability of nitrogen, phosphorus, and potassium as well as low soil $\mathrm{pH}$, so the addition of vermicompost is necessary. The purpose of this study was to determine the effect of vermicompost application on soil quality and to obtain the highest vermicompost dosage on the availability of nutrients such as N, P, K, and the yield of corn. The field experiment used a Randomized Completely Block Design (RCBD) with 7 dosages of vermicompost and three replications. The treatments were $\mathrm{V}_{0}=0 ; \mathrm{V}_{1}=5 ; \mathrm{V}_{2}=10 ; \mathrm{V}_{3}=15$; $\mathrm{V}_{4}=20 ; \mathrm{V}_{5}=25 ; \mathrm{V}_{6}=30 \mathrm{Mg} \mathrm{ha}^{-1}$. Variables observed consisted of 1) initial soil and vermicompost characterization analysis, 2) soil analysis and N, P, and K content in leaves, and yield of corn. The results showed that Entisol was classified as low quality; however, vermicompost quality complied with the requirements of quality organic fertilizer. The experiment also indicated that the highest $\mathrm{pH}$ of Entisol (5.31) and $\mathrm{K}$ content in corn leaves (2.12\%) were obtained at a dose of vermicompost $25 \mathrm{Mg} \mathrm{ha}^{-1}$. Meanwhile, the highest weight of husked corn cobs $(415.55 \mathrm{~g}$ plant $\left.{ }^{-1}\right)$ and weight of unhusked corn cob (351.11 $\left.\mathrm{g} \mathrm{plant}^{-1}\right)$ were obtained at a vermicompost dose of $15 \mathrm{Mg} \mathrm{ha}^{-1}$.
\end{abstract}

Keywords: Coastal area, corn production, entisol, vermicompost

\begin{abstract}
ABSTRAK
Kualitas tanah entisol yang rendah disebabkan oleh ketersediaan unsur hara nitrogen, fosfor, kalium dan $\mathrm{pH}$ tanah yang rendah sehingga perlu ditambah pupuk vermikompos. Tujuan penelitian ini untuk mengetahui pengaruh aplikasi pupuk vermikompos terhadap kualitas tanah dan untuk memperoleh dosis pupuk vermikompos yang tertinggi terhadap ketersediaan unsur hara N, P, K, pertumbuhan dan hasil tanaman jagung. Rancangan percobaan di lapangan menggunakan Rancangan Acak Kelompok Lengkap (RAKL) dengan 7 perlakuan dosis vermikompos dan tiga ulangan. Perlakuan dosis vermikompos yaitu: $\mathrm{V}_{0}=0 ; \mathrm{V}_{1}=5 ; \mathrm{V}_{2}=10 ; \mathrm{V}_{3}=15 ; \mathrm{V}_{4}=20 ; \mathrm{V}_{5}=25 ; \mathrm{V}_{6}=30 \mathrm{Mg}$ $\mathrm{ha}^{-1}$. Variabel pengamatan terdiri atas: 1) Analisis tanah dan vermikompos sebelum percobaan, 2) Analisis tanah, N, $\mathrm{P}, \mathrm{K}$ daun, pertumbuhan dan hasil tanaman jagung varietas BISI2 setelah percobaan. Hasil penelitian menunjukkan bahwa:1) Sebelum percobaan, kualitas tanah entisol tergolong rendah, kualitas vermikompos yang digunakan telah memenuhi syarat sebagai pupuk organik yang bermutu. 2) Setelah percobaan, $\mathrm{pH}$ tanah entisol yang tertinggi $(5,31)$ diperoleh pada dosis vermikompos $25 \mathrm{Mg} \mathrm{ha}^{-1}$. Kadar K-daun jagung yang tertinggi (2,12\%) diperoleh pada dosis vermikompos $25 \mathrm{Mg} \mathrm{ha}^{-1}$. Berat tongkol berklobot jagung yang tertinggi $\left(415,55\right.$ gram tanaman $\left.{ }^{-1}\right)$ dan berat tongkol tanpa klobot jagung yang tertinggi (351,11 gram tanaman $\left.{ }^{-1}\right)$ diperoleh pada dosis vermikompos $15 \mathrm{Mg} \mathrm{ha}^{-1}$.
\end{abstract}

Kata Kunci: Lahan pesisir, produksi jagung, entisol, vermikompos

\section{INTRODUCTION}

There is an urgency of vermicomposting research. Firstly, the vermicompost amendment can improve soil physical, chemical, and biological

\footnotetext{
J Trop Soils, Vol. 25, No. 3, 2020: 127-135

ISSN 0852-257X; E-ISSN 2086-6682
}

properties (Master Recycler Program 2018, Rogayan 2010). Soil moisture content increases with organic material derived from vermicomposting, and soil structure becomes more crumbed due to the formation of macro and micro aggregate (Tejada et al. 2010). Soil $\mathrm{pH}$ increases up to 7-8 with the application of vermicomposting (Dwiyantono et al. 2014). The application of the fertilizer also increases 
essential nutrients available to plants (Masri et al. 2016; Mahmoud and Ibrahim 2012), cation and anion exchange capacity, and base saturation, whereas reducing aluminum saturation. Vermicomposting application also increases soil organic carbon (Rogayan 2010; Punjab State Council for Science and Technology 2010) and total nitrogen (Allen 2016), the abundance of soil microorganisms (Kusumawati 2011; Mahmoud and Ibrahim2012). Secondly, the application of vermicomposting can increase the availability of essential nutrients for plants (Naturland 2018; Masri et al. 2016; Punjab State Council for Science and Technology 2010). Thirdly, the fertilizer can maintain soil fertility, soil health, and avoids soil from toxic elements ( $\mathrm{Al}, \mathrm{Fe}$, and $\mathrm{Mn}$ ), so that the soil is environmentally friendly (Rana 2018; University of Maryland 2015). Fourthly, the amendment can eliminate pests and plant diseases (Rahmawati and Herumurti 2016). Fifthly, vermicomposting can increase the yield of healthy plants, free from toxic elements and pests-diseases (Mahmoud and Ibrahim 2012). Sixth, the fertilizer can produce high-quality and odorless vermicomposting fertilizer (Dwiyanto et al. 2014; Singh et al. 2011). Seventhly, the fertilizer has a role as a soil conditioner (Tindell 2010). Eight, it can hold water $40-60 \%$ so that soil moisture is maintained (Kusumawati 2011). Mature vermicompost has characteristics: black color, smooth texture, no smell, $\mathrm{pH}$ between 6-8, moisture content of 50-60\% (Riwandi et al. 2012).

The main issues of Entisol for the cultivation of crops are stated. Firstly, Entisol is classified as relatively young, and shallow soil solum with wet, moist, or dry soil conditions (Hartati et al. 2019). Secondly, Entisol has low quality of physical properties, such as coarse soil texture. Water and nutrients are easily leached out from the solum, causing a lack of water and nutrients for plant growth and development. Thirdly, Entisol also has low quality of soil chemical properties, such as low cation and anion exchange capacity or nutrient holding capacity, leading to low availability to the plants. Fourthly, Entisol also has low soil biological properties, such as the low availability of organic matter and nitrogen for plants.

Soil quality engineering is an appropriate way to maintain soil functions within certain ecosystem limits, to preserve biological productivity, maintain environmental quality, and improve the health of plants and animals (Karlen et al. 1997). According to Karlen and Stott (1994), soils have many functions. Firstly, the soil can recycle nutrients and water. Secondly, the soil can regulate the order of water in the soil. Thirdly, the soil can maintain biodiversity and habitat for plants and animals. Fourthly, the soil can filter and refute toxic elements to maintain the quality of soil, water, and plant. Fifthly, the soil can maintain the physical stability of the soil and the carrying capacity of the soil.

The main problems of Entisol are related to physical properties (sandy soil texture), chemical properties (low nutrient availability), and biological properties (low organic $\mathrm{C}$ and total $\mathrm{N}$ ). This can be overcome by good management of vermicomposting application, including the proper method, dosage, and application time. A previous study showed that the optimum dose of vermicomposting was $7.80 \mathrm{Mg} \mathrm{ha}^{-1}$ producing $2.40 \%$ leaf $\mathrm{N}$ content, $8.60 \mathrm{Mg} \mathrm{ha}^{-1}$ having 124.8 $\mathrm{kg} \mathrm{ha}^{-1}$ leaf $\mathrm{N}$ absorption, $5.71 \mathrm{Mg} \mathrm{ha}^{-1}$ creating leaf $\mathrm{K}$ content of $0.59 \%, 9.5 \mathrm{Mg} \mathrm{ha}^{-1}$ producing $\mathrm{K}$ leaf absorption of $31 \mathrm{~kg} \mathrm{ha}^{-1}, 9.59 \mathrm{Mg} \mathrm{ha}^{-1}$ producing plant height of $160.7 \mathrm{~cm}, 10.2 \mathrm{Mg} \mathrm{ha}^{-1}$ having wet stover weight $27,561.2 \mathrm{~kg} \mathrm{ha}^{-1}, 9.89 \mathrm{Mg} \mathrm{ha}^{-1}$ producing dry stover weight $5,675.5 \mathrm{~kg} \mathrm{ha}^{-1}$, and $9.5 \mathrm{Mg} \mathrm{ha}^{-1}$ producing root dry weight $1,156 \mathrm{~kg}$ ha $^{-1}$ (Riwandi et al. 2018). The results indicated that the optimum dosage of vermicomposting fertilizer considerably varies depending on the levels and the uptake of nutrient $(\mathrm{N}, \mathrm{K})$ leaves and corn biomass. Thus, field research is necessary to obtain the optimal dosage of vermicomposting fertilizer. This study aimed to determine the effect of vermicomposting application on soil quality (soil fertility) and get the best dose of vermicomposting fertilizer on N, P, K uptakes, and corn yield.

\section{MATERIALS AND METHODS}

\section{Study Site, Experimental Design, and Treatment}

This research was conducted in July 2019 to November 2019 in Kandang Mas Village, Pulau Baai (latitude $3^{\circ} 52^{\prime} 39.5^{\prime \prime} \mathrm{S}$ to longitude $102^{\circ} 19^{\prime} 08.7^{\prime \prime}$ E), City of Bengkulu, Indonesia (Figure 1). The type of soil used was Entisol (Orthents Suborder). The experiment used a Randomized Completely Block Design (RCBD) with three replications, 7 treatments: $\mathrm{V}_{\mathrm{o}}=0 ; \mathrm{V}_{1}=5 ; \mathrm{V}_{2}=10 ; \mathrm{V}_{3}=15 ; \mathrm{V}_{4}=20 ; \mathrm{V}_{5}=25$; $\mathrm{V}_{6}=30 \mathrm{Mg}$ ha $^{-1}$ or equivalent to $\mathrm{V}_{\mathrm{o}}=0 ; \mathrm{V}_{1}=1,5$; $\mathrm{V}_{2}=3 ; \mathrm{V}_{3}=4,5 ; \mathrm{V}_{4}=6 ; \mathrm{V}_{5}=7,5 ; \mathrm{V}_{6}=9 \mathrm{~kg}$ plot $^{-1}$. The experimental plot was $3 \mathrm{~m} \times 1 \mathrm{~m}$ and the spacing was $0.75 \mathrm{~m} \times 0.20 \mathrm{~m}$, so that 20 plants were obtained per plot. The number of plots was 21 with an experimental area of $63 \mathrm{~m}^{2}$.

Vermicomposting fertilizer was taken from Air Duku village, Curup City, RejangLebong, Bengkulu, 


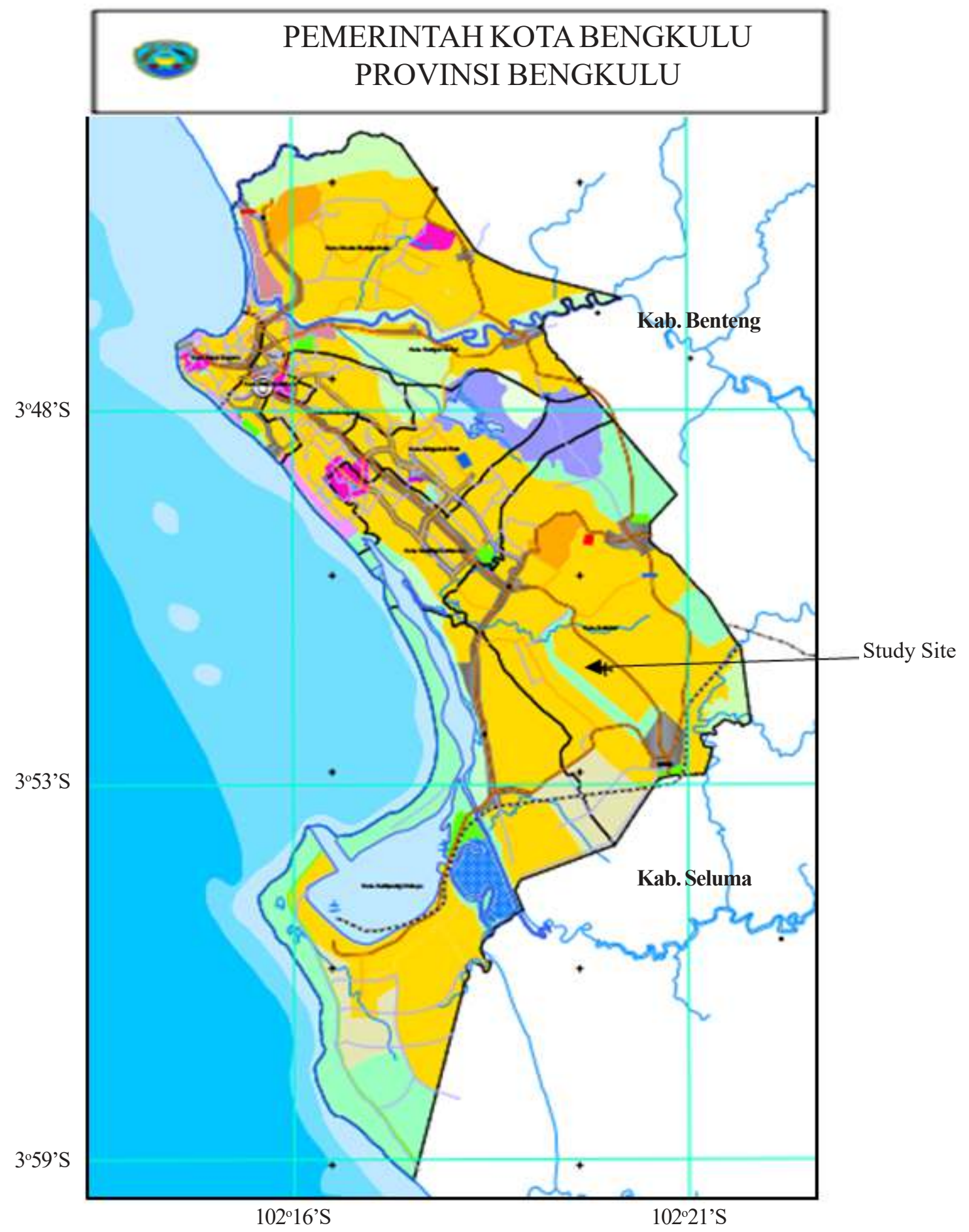

Figure 1. Study site in Kandang Mas village. Pulau Baai. Bengkulu (352’39.5"S 102¹9’08.7"E).

Regency at Wandono Farmers' Compost House. This compost house was developed by lecturers at the Faculty of Agriculture, the University of Bengkulu chaired by Prof. Ir. Zainal Muktamar, MSc., Ph.D.

\section{Soil Sampling}

The soil was classified as Entisol. A composite soil sample was randomly collected from 15 points, using a soil auger. Soil samples then was put into a bucket incorporated evenly, and approximately $2 \mathrm{~kg}$ of the sample was taken (called composite soil samples). Composite soil samples were taken to the Soil Science Laboratory for soil characteristic analysis, including organic-C by Walkley and Black method, total-N by Kjeldahl method, available-P by Bray-1 method, and $\mathrm{pH}\left(\mathrm{H}_{2} \mathrm{O}, 1: 2.5 \mathrm{w} / \mathrm{v}\right.$ ratio $)$ by $\mathrm{pH}$ meter. 


\section{Field experiment}

The land was cleaned for weed and plowed and 21 plots of $3 \mathrm{mx} 1 \mathrm{~m}$ were set up. Each plot was separated by $1 \mathrm{~m}$ and divided into 20 planting holes with a spacing of $0.75 \mathrm{~m} \times 0.20 \mathrm{~m}$. Dolomite lime, $\mathrm{Ca} \mathrm{Mg}\left(\mathrm{CO}_{3}\right)_{2}$, at a rate of $500 \mathrm{~kg} \mathrm{ha}^{-1}$ (on the basis: $0.5 \times 1 \mathrm{cmol}^{(+)} \mathrm{kg}^{-1}$ exchangeable-Al) or equivalent to $150 \mathrm{~g}$ per plot was applied to neutralize the acidity of the soil. The lime was spread into plots. Two seeds of corn varieties BISI2 incorporated with Furadan $3 \mathrm{G}$ were put into the planting hole. Furadan $3 \mathrm{G}$ was applied to prevent the seeds from insects and fungi. Replacement of seed was conducted a week after planting, if necessary.

Basal fertilizer using urea, SP36, and $\mathrm{KCl}$ was applied at the rate of $175 \mathrm{~kg} \mathrm{ha}^{-1}$ urea $(26.25 \mathrm{~g}$ per plot), $100 \mathrm{~kg} \mathrm{ha}^{-1} \mathrm{SP} 36$ (17.50 g per plot), and 50 $\mathrm{kg} \mathrm{ha}^{-1} \mathrm{KCl}(8.75 \mathrm{~g}$ per plot). The fertilizer was put into a hole approximately $2 \mathrm{~cm}$ from the corn seed. Vermicompost was spread around the planting seed corn according to the treatments.

The plant was watered every day when no rain by watering each plot using clean water. Weed was manually controlled. Pest and deceases was controlled by picking and burying the invested plants into the soil.

At the end of the vegetative stage, the leaf sample was collected by taking the corn leaves numbers 2, 3, and 4 for analysis of N, P, and K content. The leaf was cut into three parts, and the middle parts were assigned as the leaf sample for analysis. The corn was harvested at 115 days after planting, and the corn cobs were weighed.

After harvesting, a soil sample was collected and analyzed for $\mathrm{pH}\left(\mathrm{H}_{2} \mathrm{O}, 1: 2.5 \mathrm{w} / \mathrm{v}\right)$, organic-C, total-N, available-P, and exchangeable-K. $\mathrm{pH}$
$\left(\mathrm{H}_{2} \mathrm{O}, 1: 2.5 \mathrm{w} / \mathrm{v}\right)$ was measured with a $\mathrm{pH}$ meter, organic-C soil by the Walkley and Black method, total $\mathrm{N}$ by the Kjeldahl method, available $\mathrm{P}$ by the Bray I method, exchangeable $\mathrm{K}$ by $\mathrm{NH}_{4}$ Acetate $1 N$, pH 7 extraction, and measured by Flame photometer (Thom and Utomo 1991). Vermicompost was analyzed for Nitrogen $(\mathrm{N})$, Phosphorus (P), Potassium (K) by wet combustion method (Thom and Utomo 1991). Leaf sample was analyzed for N, P, and K by wet combustion method (Thom and Utomo 1991).

\section{Statistical Analysis}

The data were subjected to analysis of variance at the á level of $5 \%$. Treatment means were separated using the DMRT (Duncan's Multiple Range Test).

\section{RESULTS AND DISCUSSIONS}

\section{Initial Characteristics of Entisol and Vermicompost}

Entisol was located at lowland in Kandang Mas Village, Pulau Baai, Bengkulu, approximately $2 \mathrm{~km}$ from the beach. The Entisol was shallow (20$25 \mathrm{~cm}$ ), moist and dominated by sandy loam, slightly acidic, and exchangeable aluminum was 1 cmol $(+) \mathrm{kg}^{-1}$. The soil was as Orthents (Suborder) with flat topography conditions (Soil Survey Staff 2014). Soil analysis results showed that $\mathrm{pH}\left(\mathrm{H}_{2} \mathrm{O}\right.$, 1: $2.5 \mathrm{w} / \mathrm{v}) 5.03$, organic-C $3.34 \%$, total $0.27 \%$, available $\mathrm{P}_{2} \mathrm{O}_{5} 6.60$ ppm and exchangeable $\mathrm{K} 0.15$ cmol $(+) \mathrm{kg}^{-1}$ (Table 1). The result indicated that Entisol has low soil quality. The vermicompost characteristics were mature (black), $\mathrm{N}$ content of

Table 1. Soil chemical characteristics before field experiments.

\begin{tabular}{lccccc}
\hline Soil Code & $\begin{array}{c}\mathrm{pH} \\
\left(\mathrm{H}_{2} \mathrm{O}, 1: 2,5 \mathrm{w} / \mathrm{v}\right)\end{array}$ & $\begin{array}{c}\text { Organic-C } \\
(\%)\end{array}$ & $\begin{array}{c}\text { Total-N } \\
(\%)\end{array}$ & $\begin{array}{c}\text { Available } \mathrm{P}_{2} \mathrm{O}_{5} \\
(\mathrm{ppm})\end{array}$ & $\begin{array}{c}\text { Exchangeable-K } \\
\left(\mathrm{cmol}+\mathrm{kg}^{-1}\right)\end{array}$ \\
\hline Entisol & 5.03 & 3.34 & 0.27 & 6.60 & 0.15 \\
\hline
\end{tabular}

Table 2. Total nitrogen $(\mathrm{N})$, phosphorus $(\mathrm{P})$, and potassium $(\mathrm{K})$ content of vermicompost fertilizer.

\begin{tabular}{cccc}
\hline $\begin{array}{c}\text { Compost } \\
\text { Name }\end{array}$ & Total-N & Total-P & Total-K \\
$(\%)$ & $(\%)$ & $(\%)$ \\
\hline Vermicompost & 1.41 & 0.77 & 2.14 \\
\hline
\end{tabular}


Table 3. $\mathrm{pH}\left(\mathrm{H}_{2} \mathrm{O}\right)$, organic-C, total-C, available- $\mathrm{P}$, and exchangeable-K of Entisol after field experiments.

\begin{tabular}{cccccc}
\hline $\begin{array}{c}\text { Treatments } \\
\left(\mathrm{Mg} \mathrm{ha}^{-1}\right)\end{array}$ & $\begin{array}{c}\mathrm{pH}\left(\mathrm{H}_{2} \mathrm{O}\right) \\
(1: 2.5 \mathrm{w} / \mathrm{v})\end{array}$ & $\begin{array}{c}\text { Organic-C } \\
(\%)\end{array}$ & $\begin{array}{c}\text { Total-N } \\
(\%)\end{array}$ & $\begin{array}{c}\text { Available } \mathrm{P}_{2} \mathrm{O}_{5} \\
(\mathrm{ppm})\end{array}$ & $\begin{array}{c}\text { Exchangable-K } \\
\text { cmol }(+) \mathrm{kg}^{-1}\end{array}$ \\
\hline 0 & $4.96^{\mathrm{bc}}$ & $3.38^{\mathrm{a}}$ & $0.33^{\mathrm{a}}$ & $8.57^{\mathrm{a}}$ & $0.17^{\mathrm{a}}$ \\
5 & $4.82^{\mathrm{c}}$ & $3.77^{\mathrm{a}}$ & $0.25^{\mathrm{a}}$ & $10.65^{\mathrm{a}}$ & $0.24^{\mathrm{a}}$ \\
10 & $4.98^{\mathrm{bc}}$ & $3.50^{\mathrm{a}}$ & $0.25^{\mathrm{a}}$ & $13.99^{\mathrm{a}}$ & $0.30^{\mathrm{a}}$ \\
15 & $4.82^{\mathrm{c}}$ & $3.64^{\mathrm{a}}$ & $0.26^{\mathrm{a}}$ & $14.56^{\mathrm{a}}$ & $0.23^{\mathrm{a}}$ \\
20 & $5.19^{\mathrm{ab}}$ & $3.64^{\mathrm{a}}$ & $0.27^{\mathrm{a}}$ & $23.00^{\mathrm{a}}$ & $0.42^{\mathrm{a}}$ \\
25 & $5.31^{\mathrm{a}}$ & $3.35^{\mathrm{a}}$ & $0.27^{\mathrm{a}}$ & $17.90^{\mathrm{a}}$ & $0.45^{\mathrm{a}}$ \\
30 & $5.02^{\mathrm{c}}$ & $3.38^{\mathrm{a}}$ & $0.26^{\mathrm{a}}$ & $14.07^{\mathrm{a}}$ & $0.33^{\mathrm{a}}$ \\
\hline
\end{tabular}

$1.41 \%$, P $0.77 \%$, and $\mathrm{K} 2.14 \%$ (Table 2). Vermicompost complies with the requirements of quality organic fertilizer (Allen 2016). According to Allen (2016), complied vermicompost has $\mathrm{N}$ levels of $1.94 \%$, P $0.40 \%$, and $\mathrm{K} 0.70 \%$.

Effect of vermicompost on the quality of Entisol (pH, organic C, total $N$, available $P$, and exchangeable $K$ content)

\section{Soil pH $\left(\mathrm{H}_{2} \mathrm{O}, 1: 2.5 \mathrm{w} / \mathrm{v}\right)$}

The vermicompost dosage treatment significantly affected the $\mathrm{pH}\left(\mathrm{H}_{2} \mathrm{O}, 1: 2.5\right.$ weight/vol or w/v) of Entisol (Table 3). The highest $\mathrm{pH}$ value was 5.31 with the application of $25 \mathrm{Mg} \mathrm{ha}^{-1}$ vermicompost. The aluminum toxicity does not affect maize growth at $\mathrm{pH}$ of 5.50 because aluminum is hydrolyzed to form $\mathrm{Al}(\mathrm{OH})_{3}$, which precipitates (Bohn et al. 2007). This indicates that the soil $\mathrm{pH}$ value of 5.31 which is lower than the $\mathrm{pH}$ of 5.50 , still has a small effect on the growth of corn crops.

\section{Soil Organic-C}

The effect of the vermicompost dose on soil organic-C content was not significant (Table 3 ). However, there was a tendency for an increase in soil organic-C content with the increasing of vermicompost doses. This result might have been associated with the high initial content of soil organic-C (3.34\%), leading to a slow response to the amendment application (Jones 2012). The highest organic-C content $(3.77 \%)$ was obtained at a $5 \mathrm{Mg} \mathrm{ha}^{-1}$ vermicompost dose, meaning that there was an increase in organic $\mathrm{C}$ level of $0.43 \%$ compared to the initial content of soil organic C $(3.34 \%)$.

\section{Soil Total-N}

The effect of the vermicomposting dose on total $\mathrm{N}$ was not significant (Table 3). However, the highest total $\mathrm{N}$ level $(0.33 \%)$ was obtained without vermicomposting. This is related to that total soil $\mathrm{N}$ is the sum of ammonium, nitrite, and nitrate. The ions may be strongly bound by soil organic-C so that $\mathrm{NH}_{4}^{+}, \mathrm{NO}_{2}^{-}$, and $\mathrm{NO}_{3}^{-}$are not readily leached out of the soil profile. Another possibility is that the ions are absorbed by the roots of corn plants in ammonium and nitrate (Mengel and Kirby 1987). Soil fertilized with vermicomposting provides higher $\mathrm{N}$ for plants (Sreenivas et al. 2000) So, many plants absorb soil N. On the other hand, soil without vermicomposting is not able to provide $\mathrm{N}$ for plants. Thus, the total $\mathrm{N}$ content of Entisol without vermicomposting is the highest.

\section{Soil Available-P}

Like total N, the effect of vermicomposting dose on available $\mathrm{P}$ was not significant (Table $3)$. Nonetheless, the available P level tends to increase with the increasing vermicomposting dose. The highest available P (23 ppm) was obtained at a vermicomposting dose of $20 \mathrm{Mg}$ $\mathrm{ha}^{-1}$, while the lowest available P level (8.57 $\mathrm{ppm}$ ) without vermicomposting. This result is attributed to the supply of essential plant nutrients from vermicomposting, mainly the release of $\mathrm{P}$ to the soil, leading to an increase in soil P (Allen 2016; Tindell 2010).

\section{Soil Exchangeable $\mathrm{K}$}

The effect of vermicomposting dose on exchangeable $\mathrm{K}$ was not also significant (Table $3)$. Nevertheless, there is a tendency for an 
Table 4. Total nitrogen $(\mathrm{N})$, phosphorus $(\mathrm{P})$, and potassium $(\mathrm{K})$ levels on the leaves of the BISI2 corn crops variety after field experiments.

\begin{tabular}{cccc}
\hline $\begin{array}{c}\text { Treatment } \\
\left(\mathrm{Mg} \mathrm{ha}^{-1}\right)\end{array}$ & $\begin{array}{c}\text { Total N } \\
(\%)\end{array}$ & $\begin{array}{c}\text { Total P } \\
(\%)\end{array}$ & $\begin{array}{c}\text { Total K } \\
(\%)\end{array}$ \\
\hline 0 & $2.32^{\mathrm{a}}$ & $0.22^{\mathrm{a}}$ & $1.27^{\mathrm{c}}$ \\
5 & $2.49^{\mathrm{a}}$ & $0.20^{\mathrm{a}}$ & $1.57^{\mathrm{bc}}$ \\
10 & $2.36^{\mathrm{a}}$ & $0.20^{\mathrm{a}}$ & $1.66^{\mathrm{abc}}$ \\
15 & $2.63^{\mathrm{a}}$ & $0.24^{\mathrm{a}}$ & $1.93^{\mathrm{ab}}$ \\
20 & $2.48^{\mathrm{a}}$ & $0.19^{\mathrm{a}}$ & $1.55^{\mathrm{bc}}$ \\
25 & $2.43^{\mathrm{a}}$ & $0.22^{\mathrm{a}}$ & $2.12^{\mathrm{a}}$ \\
30 & $2.60^{\mathrm{a}}$ & $0.22^{\mathrm{a}}$ & $1.96^{\mathrm{ab}}$ \\
\hline
\end{tabular}

increase in exchangeable $\mathrm{K}$ levels with increasing vermicomposting doses. The highest exchangeable $\mathrm{K}$ levels $\left(0.45 \mathrm{cmol}(+) \mathrm{kg}^{-1}\right)$ was obtained from vermicomposting doses of $25 \mathrm{Mg} \mathrm{ha}^{-1}$, while the lowest exchangeable $\mathrm{K}$ levels $\left(0.17 \mathrm{cmol}(+) \mathrm{kg}^{-1}\right)$ was obtained at control (without vermicomposting). Vermicomposting contained high K levels (2.14\%) so that it can supply $\mathrm{K}$ into the soil. The highest dose of vermicomposting had 3 times higher soil $\mathrm{K}$ than that without vermicomposting. Vermicomposting is also able to bind $\mathrm{K}$ from inorganic fertilizer added to the soil because vermicomposting has a large surface area of particles and is negatively charged. So, vermicomposting is capable of binding $\mathrm{K}^{+}$. Vermicomposting also contains humus rich in nutrients, thereby increasing soil quality and plant growth (University of Maryland 2015).

Effect of vermicomposting on nitrogen $(\mathrm{N})$, phosphorus ( $P$ ), and potassium $(K)$ leave on the vegetative growth of BISI2 corn

\section{N-Leaves}

The effect of vermicomposting dose on $\mathrm{N}$ leaves of corn crops was not significant (Table 4). Nevertheless, the tendency of increasing levels of $\mathrm{N}$ leaves of corn crops is apparent with the addition of vermicomposting doses. The highest $\mathrm{N}$ content of leaves of corn crops (2.63\%) at vermicomposting dose of $15 \mathrm{Mg} \mathrm{ha}^{-1}$, while the lowest $(2.32 \%)$ was on Entisol without vermicomposting. According to Jones (2012), sufficient content of $\mathrm{N}$ in leaves ranges from $2.76 \%$ to $3.50 \%$. This experiment showed that leaf $\mathrm{N}$ content of corn fertilized with $15 \mathrm{Mg} \mathrm{ha}^{-1}$ of vermicomposting was $2.63 \%$, which was close to sufficient, while that of control was considered low $\mathrm{N}$.

\section{P-Leaves}

The effect of vermicomposting dose on $P$ leaves of corn was also not significant (Table 4). The highest leaf $\mathrm{P}$ content $(0.24 \%)$ was obtained at a vermicomposting dose of $15 \mathrm{Mg} \mathrm{ha}^{-1}$, while the lowest $(0.19 \%)$ was obtained with a vermicomposting dose of $20 \mathrm{Mg} \mathrm{ha}^{-1}$. The sufficient content of $\mathrm{P}$ ranges from $0.25 \%$ to $0.40 \%$ (Jones 2012). P-value of corn crop leaves in 15 and $20 \mathrm{Mg} \mathrm{ha}^{-1}$ vemicompost treatments $(0.24 \%$ and $0.19 \%)$ included low.

\section{K-Leaves}

The result of the study showed that vermicomposting significantly increased (Table $4)$. The highest $K$ content of corn crop leaf $(2.20 \%)$ was obtained at $25 \mathrm{Mg} \mathrm{ha} \mathrm{ha}^{-1}$ vermicompost dose, while the lowest K-leaves (1.27\%) without vermicomposting. Sufficient K content in corn leaf ranges from $1.71 \%$ to $2.50 \%$ (Jones 2012). The content of $\mathrm{K}$ in leaf at the treatment of $25 \mathrm{Mg} \mathrm{ha}^{-1}(2.12 \%)$ is considered sufficient, while that of control $(1.27 \%$ of $\mathrm{K})$ is categorized low.

The effect of vermicomposting on the growth and yield of corn crops varieties of BISI2

\section{Plant height}

The effect of the vermicomposting dose on corn crop height was not significant (Table 5). However, there was an increase in corn crop height with increasing doses of vermicomposting. The highest plant height of the corn crop (189.38 $\mathrm{cm}$ ) was obtained at $25 \mathrm{Mg} \mathrm{ha}^{-1}$ vermicomposting dose, while the lowest plant height $(153.00 \mathrm{~cm})$ was obtained without vermicomposting. 
Table 5. Plant Height (pH), Weight of Corncob (W1), Weight of Corncob Without Cornhusk (W2), Dry Weight of Corn Kernels (DWCK) BISI2 corn after field experiments.

\begin{tabular}{ccccc}
\hline $\begin{array}{c}\text { Treatment } \\
\left(\mathrm{Mg} \mathrm{ha}^{-1}\right)\end{array}$ & $\begin{array}{c}\text { PH } \\
(\mathrm{cm})\end{array}$ & $\begin{array}{c}\text { W1 } \\
\left(\mathrm{g} \mathrm{plant}^{-1}\right)\end{array}$ & $\begin{array}{c}\text { W2 } \\
\left(\mathrm{g} \mathrm{plant}^{-1}\right)\end{array}$ & $\begin{array}{c}\text { DWCK } \\
\left(\mathrm{g} \mathrm{plant}^{-1}\right)\end{array}$ \\
\hline 0 & $153.00 \mathrm{a}$ & $275.55 \mathrm{~b}$ & $238.89 \mathrm{~b}$ & $169.99 \mathrm{a}$ \\
5 & $178.55 \mathrm{a}$ & $332.22 \mathrm{ab}$ & $289.44 \mathrm{ab}$ & $183.61 \mathrm{a}$ \\
10 & $187.08 \mathrm{a}$ & $337.77 \mathrm{ab}$ & $293.88 \mathrm{ab}$ & $183.88 \mathrm{a}$ \\
15 & $188.72 \mathrm{a}$ & $415.55 \mathrm{a}$ & $351.11 \mathrm{a}$ & $223.88 \mathrm{a}$ \\
20 & $181.11 \mathrm{a}$ & $402.77 \mathrm{a}$ & $345.55 \mathrm{a}$ & $210.00 \mathrm{a}$ \\
25 & $189.38 \mathrm{a}$ & $367.22 \mathrm{a}$ & $316.11 \mathrm{ab}$ & $213.33 \mathrm{a}$ \\
30 & $186.05 \mathrm{a}$ & $388.33 \mathrm{a}$ & $331.66 \mathrm{a}$ & $215.33 \mathrm{a}$ \\
\hline
\end{tabular}

Compared to the height of corn crops planted on LESS FERTILE SOIL (equivalent to Entisol), the highest corn plant height was $74.33 \mathrm{~cm}$ when applying $20 \mathrm{Mg} \mathrm{ha}^{-1}$ compost (Riwandi et al. 2015). This means that there is a difference in the height of $115.05 \mathrm{~cm}$ corn crops at $25 \mathrm{Mg} \mathrm{ha}^{-1}$ vermicompost dose. The reason is the quality of vermicomposting fertilizer is better than compost, especially N, $\mathrm{P}$, and $\mathrm{K}$ levels. A previous study noted that vermicomposting contained $\mathrm{N} 1.41 \%, \mathrm{P} 0.77 \%$, and $\mathrm{K} 2.14 \%$, whereas compost fertilizer had $\mathrm{N}$ levels of $0.67 \%$, $\mathrm{P} 0.75 \%$, and $\mathrm{K} 1.80 \%$ (Riwandi et al. 2015). Nutrients N, P, and K play a significant role in increasing the growth of corn, including plant height.

\section{Weight of husked Corn cob}

The vermicomposting dose had a significant effect on the weight of husked corn (Table 5). The highest corncob weight (415.55 g plant $\left.^{-1}\right)$ was obtained at a vermicomposting dose of 15 $\mathrm{Mg} \mathrm{ha}^{-1}$. In comparison, the lowest $(275.55 \mathrm{~g}$ plant $^{-1}$ ) was obtained without vermicomposting. When compared to the weight of the husked corncob planted on LESS FERTILE SOIL (equivalent to entisols), the highest weight of the husked corncob was $273.73 \mathrm{~g} \mathrm{plant}^{-1}$ on at the application of compost of $18.75 \mathrm{Mg} \mathrm{ha}^{-1}$ (Riwandi et al.2015). The weight of husked corn cob using vermicomposting was 1.5 higher than the compost. The large difference is due to the same reason where vermicomposting has higher $\mathrm{N}, \mathrm{P}$, and content than compost.

\section{Weight of unhusked Corncob}

The vermicomposting application had a significant effect on the weight of unhusked corn cob (Table 5). The highest weight of unhusked corncob (351.11 $\left.\mathrm{g} \mathrm{plant}^{-1}\right)$ was obtained at a vermicomposting dose of $15 \mathrm{Mg} \mathrm{ha}^{-1}$, while the lowest (238.89 g plant $^{-1}$ ) was obtained without vermicomposting When compared to the weight of unhusked corncob cultivated in less fertile soil (equivalent to entisols), the highest weight of unhusked corncob was $164.38 \mathrm{~g} \mathrm{plant}^{-1}$ at the application of compost of $18.75 \mathrm{Mg} \mathrm{ha}^{-1}$ (Riwandi et al. 2015). The reason is similar to that previously mentioned where vermicomposting has higher nutrient content ( $\mathrm{N}, \mathrm{P}$, and $\mathrm{K}$ ) than compost. The results showed the weight of unhusked corncob at a vermicompost dose of 15 $\mathrm{Mg} \mathrm{ha}^{-1}$ is 2.1 higher than that of a compost dose of $18.75 \mathrm{Mg} \mathrm{ha}^{-1}$.

\section{Dry Weight of Corn Kernels}

The dry weight of the corn kernel was not significantly affected by vermicomposting (Table 5). However, there was an increase in the dry weight of corn kernels with increasing vermicomposting dose. The highest dry weight of corn kernels (223.88 $\left.\mathrm{g}_{\text {plant }}{ }^{-1}\right)$ at a vermicomposting dose of $15 \mathrm{Mg} \mathrm{ha}^{-1}$, while the lowest (169.99 $\left.\mathrm{g} \mathrm{plant}^{-1}\right)$ without vermicomposting. When compared with the dry weight of corn kernels planted on less fertile soil (equivalent to entisols), the highest dry weight of corn kernels was $104.43 \mathrm{~g} \mathrm{plant}^{-1}$ at the compost dose of $18.75 \mathrm{Mg} \mathrm{ha}^{-1}$ (Riwandi et al. 2015), vermicomposting application at a dose of $15 \mathrm{Mg}$ ha $^{-1}$ provided 2.1 higher dry weight of corn kernels than that compost dose of $18.75 \mathrm{Mg} \mathrm{ha}^{-1}$.

\section{CONCLUSIONS}

The application of vermicomposting can improve soil quality, consequently enhance corn production characterized by significantly higher $\mathrm{pH}$ of Entisol, leaf $\mathrm{K}$ content, and yield of corn crops. The highest $\mathrm{pH}$ of Entisol (5.31) and corn 
leaf $\mathrm{K}$ content $(2.12 \%)$ were obtained at a vermicomposting dose of $25 \mathrm{Mg} \mathrm{ha}^{-1}$. The highest weight of corncob (415.55 $\left.\mathrm{g} \mathrm{plant}^{-1}\right)$ and the highest weight of unhusked corn cob $(351.11 \mathrm{~g}$ plant $\left.^{-1}\right)$ were obtained at a vermicomposting dose of $15 \mathrm{Mg} \mathrm{ha}^{-1}$.

\section{ACKNOWLEDGMENTS}

The authors would like to thank the Research and Community Service Institute, University of Bengkulu, for providing financial support through the DIPA-University of Bengkulu with the-Letter of Appointment for the Fiscal Year 2019 number: 2171 / UN30.15 / LT / 2019 profusely.

\section{REFERENCES}

Allen J. 2016. Vermicomposting. Guide H-164 (Revised). Cooperative Extention Service. College of Agricultural, Consumer and Environmental Sciences. New Mexico State University. https:// aces.nmsu.edu/pubs/_h/H164/welcome.html. (Accessed on June 7, 2020)

Bohn HL, BL McNeal and GA O'Connor. 2007. Soil Chemistry. John Wiley \& Sons. New York. 329p.

Dwiyantono R, Sutaryo and A Purnomoadi. 2014. Perbandingan kualitas vermikompos yang dihasilkan dari feses sapi dan feses kerbau. Animal Agric J 3: 147-154. (in Indonesian).

Hartati S, Suryono and LS Purnama. 2019. The potential of potassium fertilizers in improving the availability and uptake of potassium in rice grown on entisol. $J$ Trop Soils 24: 83-91.

Jones Jr JB. 2012. Plant Nutrition and Soil Fertility Manual. Boca Raton: CRC Press. 230p.

Karlen DL and DE Stott DE. 1994. Framework for evaluating physical and chemical indicators of soil quality. In: JW Doran, DC Leman, DF Bezdicek and BA Stewart (eds). Defining soil quality for a sustainable environment: Proceedings of a symposium, Minneapolis, MN, USA, 4-5 November 1992. Soil Sci Soc Am, Inc., Madison, WI, pp. 53-72.

Karlen DL, MJ Mausbach, JW Doran, RG Cline, RF Harris and GE Schuman. 1997. Soil quality: A concept, definition, and framework for evaluation. Soil Sci Soc Am J 61: 4-10.

Kusumawati N. 2011. Evaluasi perubahan temperatur, $\mathrm{pH}$ dan kelembaban media pada pembuatan vermikompos dari campuran jerami padi dan kotoran sapi menggunakan Lumbricus Rubellus. Inotek 15: 45-56 (in Indonesian).

Mahmoud EK and MM Ibrahim. 2012. Effect of vermicompost and its mixtures with water treatment residuals on soil chemical properties and barley growth. J Soil Sci Plant Nutr 12: 431-440.
Masri IN, NHA Bakar, WAW Yusoff and MH Basir. 2016. Penghasilan vermikompos menggunakan bahan sisa buangan pertanian. Buletin Teknologi MARDI, Bil 10: 29-35 (in Indonesian).

Master Recycler Program. 2018. Chapter Two: Composting \& Vermicomposting. pp 17-44.

Mengel K and EA Kirby. 1987. Principles of Plant Nutrition 4th eds. International Potash Institute. Switzerland. $687 \mathrm{p}$.

Naturland. 2018. Vermicompost high-grade fertilizer for improved soil fertility. Naturland Producer Info. Naturland International. 22 p.

Punjab State Council for Science and Technology. Chandigarh. 2010. Retrievedon September 30, 2010, from http://agri.and.nic.in/vermi_culture.htm (Accessed on June 7, 2020).

Rahmawati E and W Herumurti. 2016. Vermikompos sampah kebun dengan menggunakan cacing tanah Eudrilus Eugeneae dan Eisenia Fetida. Jurnal Teknik ITS 5: C33-C37. (in Indonesian).

Rana SS. 2018. Biological Intensive Nutrient Management: Vermicompost. BINM: Vermicompost. $45 \mathrm{p}$.

Riwandi, Hasanudin and Anandyawati. 2018. Rekayasa kualitas tanah dengan vermikompos dan aplikasinya terhadap hasil tanaman jagung. Laporan Akhir Penelitian Mandiri, Universitas Bengkulu. unpublished, 35p (in Indonesian).

Riwandi, M Handajaningsih and Hasanudin. 2012. Teknologi Tepat Guna Pupuk kompos dan teknologi pembuatannya. Unib Press. University of Bengkulu. Bengkulu, 54p (in Indonesian).

Riwandi, M Handajaningsih, Hasanudin and A Munawar. 2015. Soil quality improvement using compos and its effects on organic-corn production. J Trop Soils 20: 11-19.

Rogayan Jr D. 2010.Vermiculture and vermicomposting. Ramon Magsaysay Technological University. San Marcelino, Zambales. 23 p

Singh RP, P Singh, ASF Araujo, MH Ibrahim and O Sulaiman 2011. Management of urban solid waste: Vermicomposting a sustainable option. Resour. Conserv Recycl 55: 719-729.

Soil Survey Staff. 2014. Keys to Soil Taxonomy $12^{\text {th }}$ ed. USDA-Natural Resources Conservation Service, Washington, DC. 372 p.

Sreenivas C, S Muralidha and MS Rao. 2000. Vermicompost, a viable component of IPNSS in nitrogen nutrition of ridge gourd. Ann Agr Res 21: 108-113.

Tejada M, I Gomez, T Hernandez and C Garcia. 2010. Utilization of vermicomposts in soil restoration: Effects of soil biological properties. Soil Sci Soc Am J 74: 525-532.

Thom WO and M Utomo. 1991. Manajemen laboratorium dan metode analisis tanah dan tanaman. Penerbit Universitas Lampung. Bandar Lampung. 85 halaman (in Indonesian). 
Tindell JP. 2010. How to vermicompost at home or work. Best sustainable practices. Department of Parks and Recreation 915 I Street, 5th Fl, Sacramento, CA 95814. 10 pages. www.cityofsacramento.org/ parksandrecreation/pdf/vermicompost-01-08-09.pdf (Accessed on March 6, 2020).
University of Maryland. 2015. Earthworms and vermicomposting. Women in Agriculture Training manual for female extension educators. College of Agriculture and Natural Resources. Department of Agricultural and Resource Economics. 6 p. 